\title{
MODELING THE NERVE IMPULSE TRANSMISSION IN A SYNAPTIC CLEFT
}

\author{
O. V. Kulish, A. N. Vasilev \\ Taras Shevchenko National University of Kyiv, Department of Theoretical Physics, \\ 60, Volodymyrska St., Kyiv, Ukraine \\ e-mail: alex@vasilev.kiev.ua \\ (Received September 30, 2018; in final form - December 24, 2018)
}

\begin{abstract}
We propose a model of the nerve impulse spreading through a synaptic cleft (chemical synapse). The model takes into account the diffusion of the mediator in the synaptic cleft and the interaction of the mediator with the receptors on the postsynaptic membrane. We consider a system of two equations. One of them describes the diffusion of the mediator in the synaptic cleft, and the other describes the interaction of the mediator with the receptors on the postsynaptic membrane. This is the key process of the nerve impulse transmission since activating the receptors leads to generating a new nerve impulse, which spreads through the contacting neuron. We find an analytical solution for the system of equations, and on the basis of this solution, we calculate some important characteristics which determine the regime of the nerve impulse transmission. In particular, we find how the number of activated receptors changes with time, and how these activated receptors are distributed within the postsynaptic membrane. We also calculate the size of the activation zone of the postsynaptic membrane and show that it is proportional to the size of the activation zone of the presynaptic membrane. Moreover, we investigate how the thickness of the synaptic cleft affects the activation characteristics of the synapse. We find that increasing the thickness of the cleft decreases the size of the activation zone of the postsynaptic membrane.
\end{abstract}

Key words: nerve impulse, synapse, mediator, receptor, membrane, activation zone.

DOI: https://doi.org/10.30970/jps.23.1801

PACS number(s): 89.75.Fb, 87.10.+e, 87.16.Xa

\section{INTRODUCTION}

The problem of synaptic transmission has a long story, and many interesting results were received in this area [1-4]. Nevertheless, it is still of great importance today. General physiological aspects of the chemical transmission are known, but when we try to model the total process, we face some mathematical difficulties. The main problem here is that the synaptic transmission is too complex to describe within a single model. As usual, we have to use several models that are applicable at different stages of the process. Next we propose a model that describes the mediator transportation in the synaptic cleft and the interaction of the mediator with receptors on the postsynaptic membrane. The presented paper belongs to the series of works [5-14] which are devoted to the problem of synaptic transmission.

So, as is well known, a synapse is a contact or junction between two neurons. It consists of the presynaptic membrane (a membrane of a neuron that spreads a signal), the postsynaptic membrane (a membrane of the neuron that gets a signal), and the synaptic cleft between them (the general structure of a chemical synapse is presented in Fig. 1). The presynaptic membrane contains a chemical substance - the mediator (for example, it can be acetylcholine). The mediator is stored in special containers, which are called vesicles. When the nerve impulse arrives, it leads to releasing the mediator into the synaptic cleft [15]. Releasing the mediator into the cleft is called exocytosis. Then, due to diffusion, the mediator moves to the postsynaptic cleft [16-18]. The postsynap- tic membrane contains receptors. The mediator interacts with the receptors, and they evolve to activated states that can be the cause of generating a new impulse. In general, this is the main sequence of events which occur while a nerve signal passes through the synapse. As was mentioned above, in this paper we propose a model, which is applicable for describing the synaptic transmission right from the mediator exocytosis and until the receptors' activation.

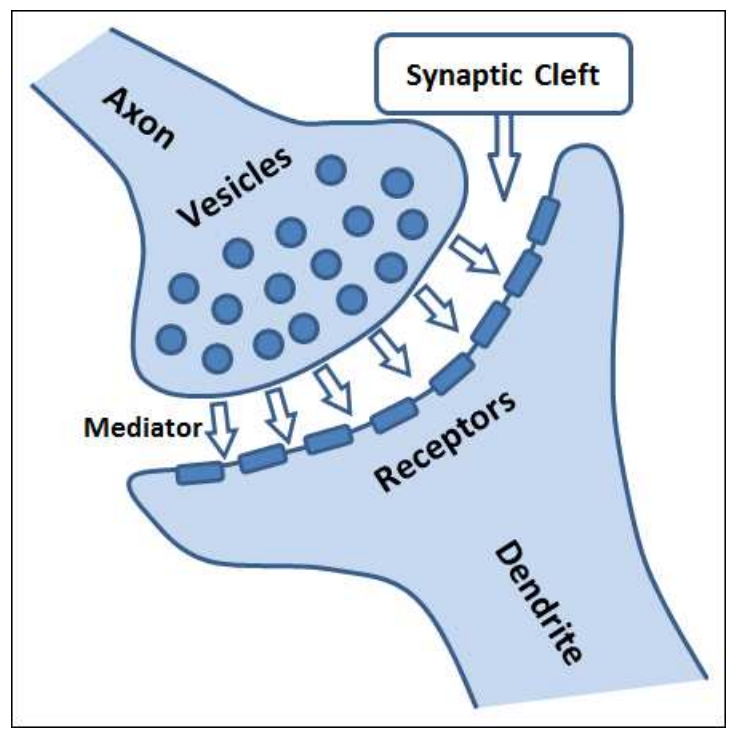

Fig. 1. The general structure of a chemical synapse: the presynaptic membrane, the postsynaptic membranes, and the synaptic cleft between them 


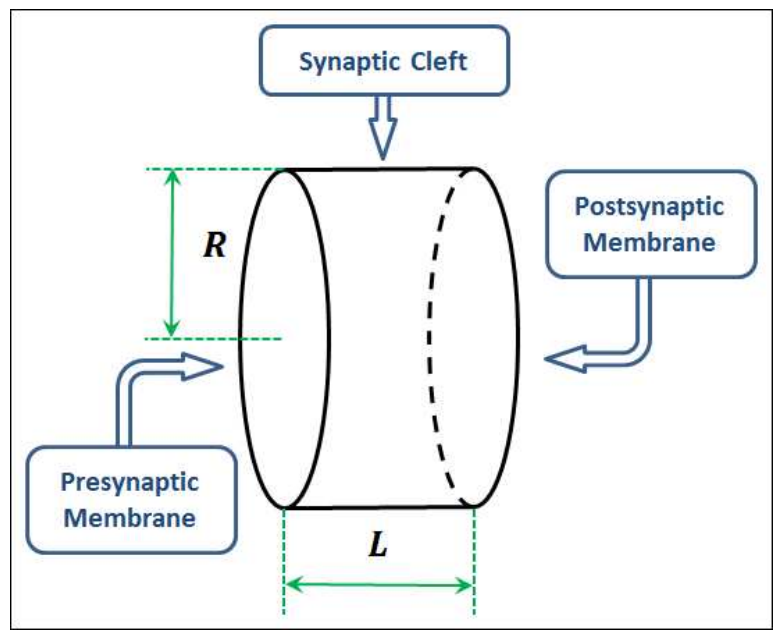

Fig. 2. The geometry of the system: a restricted cylinder of radius $R$ and of height $L$. The bases of the cylinder correspond to the presynaptic and postsynaptic membranes. The area between the bases stands for the synaptic cleft

\section{MATHEMATICAL MODEL}

Thus, we consider a synaptic cleft between two membranes: the presynaptic membrane and the postsynaptic membrane. We assume that the geometry of the system is a restricted cylinder: it is of radius $R$ and its height is $L$ (the geometry of the system is illustrated in Fig. 2). If so, then $0 \leq \rho \leq R$ determines the distance from the cylinder axis to the point within the cleft, and $0 \leq z \leq L$ determines the distance (along the cylinder axis) from the presynaptic membrane to the point within the system. It is clear that the presynaptic membrane is placed at the position $z=0$, and the postsynaptic membrane is placed at the coordinate $z=L$. Let us also define $U(t, \rho, z)$ to be the mediator concentration inside the synaptic cleft. It depends on time $t$ and spatial coordinates $\rho$ and $z$ (we assume that the mediator concentration doesn't depend on the azimuthal angel, which means that we consider the system with cylindrical symmetry). The base equation of our model describes the diffusion of the mediator inside the synaptic cleft and is of well-known form:

$$
\frac{\partial U(t, \rho, z)}{\partial t}=D \Delta U(t, \rho, z)
$$

Here $D$ stands for the diffusion coefficient, and $\Delta$ is the Laplace operator.

This equation should be complemented by boundary conditions. As was mentioned above, the mediator is injected into the synaptic cleft from the presynaptic membrane. We consider the situation right after the mediator is released into the cleft. If so, the flux of the mediator through the presynaptic membrane should be zero, and we have the following boundary condition:

$$
\left.\frac{\partial U(t, \rho, z)}{\partial z}\right|_{z=0}=0 .
$$

We also assume that the mediator cannot spread through the side wall of the cylinder. This gives us another bound- ary condition:

$$
\left.\frac{\partial U(t, \rho, z)}{\partial \rho}\right|_{\rho=R}=0
$$

Actually, this condition presents the situation in a simplified form. The fact is that in the general case the mediator can spread out of the synaptic cleft [19]. So condition (3) should be more sophisticated. Nevertheless, and it will be shown later, we are going to consider the case when the mediator is located in the central area of the cleft. This annihilates the influence of the boundary condition at the side wall of the cylinder. Taking this condition in the form of relation (3), we simplify the total solution and, simultaneously, we do not affect it qualitatively.

When the mediator reaches the postsynaptic membrane, it interacts with the receptors on the membrane. Actually, we can consider the situation as if the mediator were captured by the receptors. If so, then we can consider the zeroth boundary condition for $U(t, \rho, z)$ at the postsynaptic membrane:

$$
U(t, \rho, L)=0 .
$$

The initial condition determines how the mediator is distributed in the synaptic cleft at the beginning:

$$
U(0, \rho, z)=\phi(\rho, z),
$$

where $\phi(\rho, z)$ is the spatial distribution of the mediator right after it has been released into the cleft.

Actually, if we know the initial distribution of the mediator $\phi(\rho, z)$, we can easily solve the task (equation (1) with boundary conditions (2)-(4) and initial condition $(5))$. But we are mostly interested in finding the distribution of the activated receptors on the postsynaptic membrane. Here we will use a simplified scheme of the receptors' activation which, on the one hand, allows us to qualitatively estimate the dynamics of the activated receptors and, on the other hand, it does not complicate the model too much.

Let $V(t, \rho)$ be the number of activated receptors on the postsynaptic membrane (more precisely, it is the density of activated receptors in the region with coordinate $\rho$ ). To determine how the number of the activated receptors changes in time, we use the following kinetic equation:

$\frac{\partial V(t, \rho)}{\partial t}=-\left.k_{1}\left(V_{0}-V(t, \rho)\right) \frac{\partial U(t, \rho, z)}{\partial z}\right|_{z=L}-k_{2} V(t, \rho)$.

In this equation, $V_{0}$ is the total number of receptors on the postsynaptic membrane. We assume that a change in the number of activated receptors can be caused by two reasons:

- Those receptors that are not activated yet can evolve to the activated state. We consider the rate of this process to be proportional to the number of non-activated receptors (the value $V_{0}-V(t, \rho)$ ), and also it is proportional to the mediator flux at the postsynaptic membrane (this flux is proportional to the derivative $\left.\frac{\partial U(t, \rho, z)}{\partial z}\right|_{z=L}$ with the "minus" sign). 
- Activated receptors can become non-activated. The rate of this transformation is proportional to the number of activated receptors $V(t, \rho)$.

If the initial number of activated receptors is zero, then equation (6) should be complemented by the initial condition

$$
V(0, \rho)=0 .
$$

Thus, to calculate the number of activated receptors on the postsynaptic membrane, we have to solve the problem (1)-(5), find the function $U(t, \rho, z)$, and then use it to find the solution $V(t, \rho)$ of the problem defined by equations (6) and (7).

\section{GENERAL SOLUTION}

To simplify the initial system of equations, it is reasonable to make a set of substitutions. Namely, we use such new variables and functions: $x=z / L, r=\rho / R, \tau=$ $t D / L^{2}, u(\tau, r, z)=L k_{1} U(r, z, t) / D, v(\tau, r)=V(t, r) / V_{0}$. In this case we get the following equations:

$$
\begin{array}{r}
\frac{\partial u(\tau, r, x)}{\partial \tau}=\frac{\partial^{2} u(\tau, r, x)}{\partial x^{2}}+\frac{1}{K^{2}} \Delta_{r} u(\tau, r, x), \\
\frac{\partial v(\tau, r)}{\partial \tau}=-\left.(1-v(\tau, r)) \frac{\partial u(\tau, r, x)}{\partial x}\right|_{x=1}-\lambda v(\tau, r),
\end{array}
$$

where we have used the definitions $K=R / L$ and $\lambda=k_{2} L^{2} / D$. Boundary conditions become as follows:

$$
\begin{array}{r}
\left.\frac{\partial u(\tau, r, x)}{\partial x}\right|_{x=0}=0, \\
\left.\frac{\partial u(\tau, r, x)}{\partial r}\right|_{r=1}=0, \\
u(\tau, r, 1)=0 .
\end{array}
$$

Initial conditions are transformed to the following:

$$
\begin{array}{r}
u(0, r, x)=\phi(r, x), \\
v(0, r)=0 .
\end{array}
$$

The solution $u(\tau, r, x)$ of the problem (8)-(14) can be presented in this form:

$$
\begin{aligned}
u(\tau, r, x) & =\sum_{m=0}^{\infty} \sum_{n=0}^{\infty} \phi_{n m} \exp \left(-\eta_{n m} \tau\right) \\
& \times \cos \left(\frac{(2 m+1) \pi x}{2}\right) J_{0}\left(\mu_{n} r\right) .
\end{aligned}
$$

Here $J_{0}(\cdot)$ is the Bessel function of order zero, $\mu_{n}(n=$ $0,1,2, \ldots)$ are zeros of the Bessel function $J_{1}(\cdot)$ of order one (roots of $J_{1}\left(\mu_{n}\right)=0$ ), and coefficients $\phi_{n m}$ are determined in this way:

$$
\begin{aligned}
\phi_{n m} & =\frac{4}{J_{0}\left(\mu_{n}\right)^{2}} \int_{0}^{1} \int_{0}^{1} \phi(r, x) r J_{0}\left(\mu_{n} r\right) \\
& \times \cos \left(\frac{(2 m+1) \pi x}{2}\right) d r d x
\end{aligned}
$$

In equation (15), we have also used the parameter

$$
\eta_{n m}=\left(\frac{\mu_{n}}{K}\right)^{2}+\left(\frac{(2 m+1) \pi}{2}\right)^{2}
$$

After finding function $u(\tau, r, x)$, we can calculate the expression

$$
\begin{aligned}
\left.\frac{\partial u}{\partial x}\right|_{x=1} & =\frac{\pi}{2} \sum_{m=0}^{\infty} \sum_{n=0}^{\infty}(2 m+1)(-1)^{m+1} \\
& \times \phi_{n m} \exp \left(-\eta_{n m} \tau\right) J_{0}\left(\mu_{n} r\right)
\end{aligned}
$$

and then find function $v(\tau, r)$ according to the equation

$$
\begin{aligned}
v(\tau, r) & =1-\exp (\psi(\tau, r)-\lambda \tau) \\
& \times\left(1+\lambda \int_{0}^{\tau} \exp (\lambda t-\psi(t, r)) d t\right),
\end{aligned}
$$

where function $\psi(\tau, r)$ is determined as follows:

$$
\psi(\tau, r)=\left.\int_{0}^{\tau} \frac{\partial u(t, r, x)}{\partial x}\right|_{x=1} d t=\frac{\pi}{2} \sum_{m=0}^{\infty} \sum_{n=0}^{\infty}(-1)^{m+1} \phi_{n m} \frac{2 m+1}{\eta_{n m}}\left(1-\exp \left(-\eta_{n m} \tau\right)\right) J_{0}\left(\mu_{n} r\right) .
$$

In fact, equations (15)-(20) allow us to find the distribution of the mediator in the synaptic cleft, as well as the number of activated receptors. All we have to know for that is the initial distribution of the mediator in the synaptic cleft, which is determined by function $\phi(r, x)$.

\section{ACTIVATION ZONE}

It is known that the mediator injection takes place only in special areas of the presynaptic membrane [20,21]. We will term the area where the mediator is located an "activation zone". During exocytosis, the mediator is being injected through the presynaptic membrane into the synaptic cleft. In our model, parameters of the activation zone are determined by the initial condition for the mediator distribution. Moreover, it is clear that the initial condition affects the solution not only quantitatively but also qualitatively. So it is important to consider those conditions that could be realized and observed in real systems. Our suggestions are as follows. We assume that when exocytosis happens, then the intensity of the mediator flux decreases proportionally to the distance along 
the direction of the mediator injection. If $I(r, z)$ is the intensity of the mediator flux, then everything mentioned above means that

$$
\frac{1}{I} \frac{\partial I}{\partial x}=-2 \alpha x
$$

where $\alpha$ is some parameter, and this gives us the following:

$$
I(r, x)=I_{0}(r) \exp \left(-\alpha x^{2}\right) .
$$

Function $I_{0}(r)$ actually determines the activation zone on the presynaptic membrane. We will assume that vesicles, which store the mediator, are distributed normally around the center of the presynaptic membrane. Also, it is natural to suppose that the initial distribution of the mediator in the cleft is proportional to the mediator injection intensity. If so, then we can consider such initial distribution of the mediator in the cleft:

$$
\phi(r, x)=2 A \frac{\sqrt{\alpha} \beta}{\pi^{3 / 2}} \exp \left(-\alpha x^{2}-\beta r^{2}\right)
$$

where $\beta$ is a phenomenological parameter, and parameter $A$ determines the total amount of the mediator within the cleft.

Knowing the initial distribution of the mediator $\phi(r, x)$ allows us to calculate how the number of activated receptors on the postsynaptic membrane $v(\tau, r)$ depends on time $\tau$ and coordinate $r$. It is clear that this dependence should be calculated numerically. For the calculations, we have taken the values $K=10$ and $\lambda=0.5$. We also use the values $\alpha=1000, \beta=20$ and $A=1$. If we apply the "three-sigma rule", then we can interpret the parameter $s=\frac{3}{\sqrt{2 \alpha}} \approx 0.067$ as the depth of the mediator injection into the synaptic cleft, and $d=\frac{3}{\sqrt{2 \beta}} \approx 0.47$ as the radius of the activation zone of the presynaptic membrane. The results of the calculations are presented in Fig. 3.

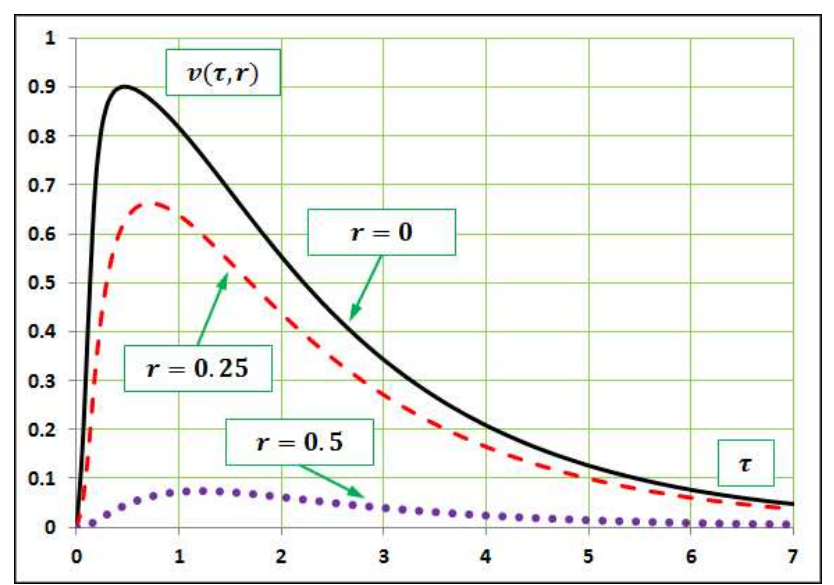

Fig. 3. Dependence $v(\tau, r)$ for fixed value of $r$ (the solid line is for the value $r=0$, the dashed line is for the value $r=0.25$, and the dotted line is for the value $r=0.5)$. Calculations were performed by taking the values $K=10$ and $\lambda=0.5$
The figure contains plots for dependence $v(\tau, r)$ for several fixed values of $r$. In particular, we consider the values $r=0, r=0.25$ and $r=0.5$. In every case, the number of activated receptors increases to the maximum value, and then comes back to zero. It is also expectable that the value of the maximum is greater for small distances $r$.

The distribution of activated receptors on the postsynaptic membrane (actually, dependence of $v(\tau, r)$ on $r$ for fixed $\tau$ ) is presented in Fig. 4. We have considered the spatial distribution of activated receptors at the time moments $\tau=1, \tau=2$ and $\tau=3$. We see from the figure that for times $\tau \geq 1$ the number of activated receptors decreases, and the activation zone of the postsynaptic membrane (the area on the postsynaptic membrane where the activated receptors are located) is still more or less the same.

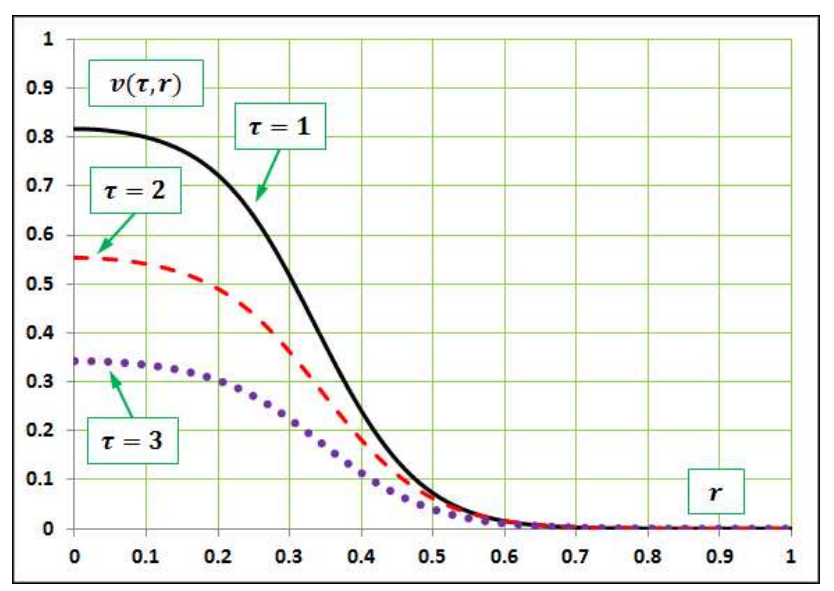

Fig. 4. Dependence $v(\tau, r)$ for fixed values of $\tau$ (the solid line is for the value $\tau=1$, the dashed line is for the value $\tau=2$ and the dotted line is for the value $\tau=3$ ). Calculations were performed by taking the values $K=10$ and $\lambda=0.5$

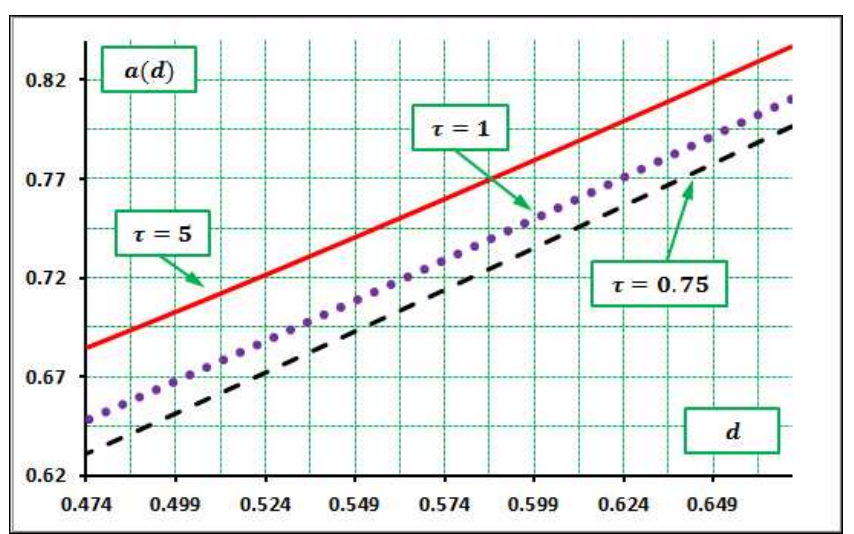

Fig. 5. Dependence of the size of the activation zone of the postsynaptic membrane $a$ on the size of the activation zone of the presynaptic membrane $d$. The solid line is for the time $\tau=5$, the dotted line is for the time $\tau=1$ and the dashed line is for the time $\tau=0.75$. Calculations were performed by taking the values $K=10$ and $\lambda=0.5$ 


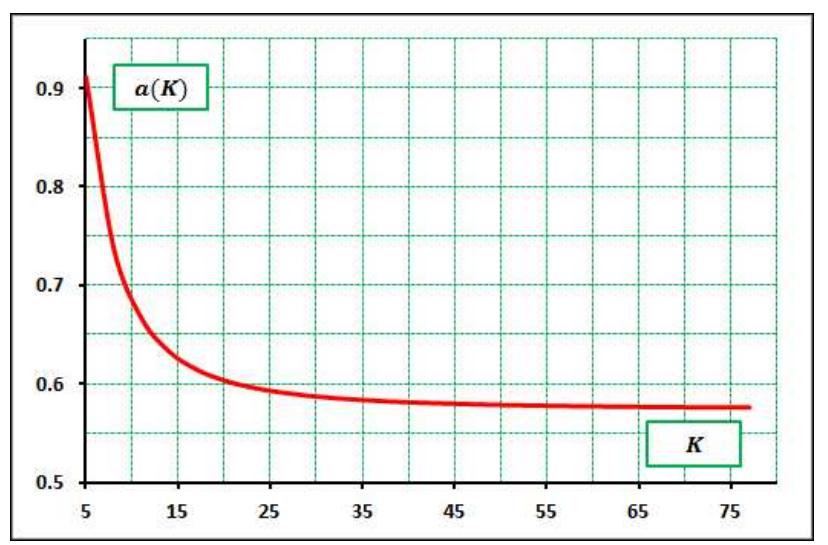

Fig. 6. Dependence of the size of the activation zone of the postsynaptic membrane $a$ on the geometric factor $K$. Calculations were performed by taking the values $\tau=5$ and $\lambda=0.5$

To estimate the size of the activation zone of the postsynaptic membrane we can use the following parameter

$$
a(\tau)=3 \sqrt{\frac{1}{2} \cdot \frac{\int_{0}^{1} v(\tau, r) r^{3} d r}{\int_{0}^{1} v(\tau, r) r d r}}
$$

If the activated receptors were normally distributed, then parameter $a(\tau)$ would give the "three-sigma" length. For times $2<\tau<7$, numerical calculations give the value of the radius of the activation zone $a(\tau) \approx 0.68$, and it almost does not change with time. But in the general case, it depends on time and other parameters, including the size of the activation zone of the presynaptic membrane $d$. Fig. 5 contains plots that illustrate how the size of the activation zone of the postsynaptic membrane (calculated according to equation (24)) changes with changing the size of the activation zone of the presynaptic membrane (which is calculated as $d=\frac{3}{\sqrt{2 \beta}}$ ).

We see that this dependence is actually linear (for different moments of time). This is an important result, since it means that if we somehow change the activation zone of the presynaptic membrane then the activation zone of the postsynaptic membrane changes as well (and this change is proportional to the change of the activation zone of the presynaptic membrane).

Within our model, the mediator is spread to the postsynaptic membrane by means of diffusion. So it is clear that the size of the area, which will be filled with the mediator, should depend on the geometrical parameters of the synaptic cleft. Fig. 6 demonstrates how the size of the activation zone of the postsynaptic membrane depends on the geometric factor $K=\frac{R}{L}$. It appears that the size of the zone increases with decreasing the geometric factor $K$. If we increase the geometric factor, then the size of the activation zone decreases and reaches some saturation level. To understand this, we should take into account that increasing the geometric factor is equivalent to decreasing the width of the synaptic cleft $L$. From a physical point of view, this behavior is totally expectable. Indeed, if we consider a very thin synaptic cleft (whose thickness is close to zero), then the size of the activation zone of the postsynaptic membrane should be very close to the size of the activation zone of the presynaptic membrane. On the other hand, if the thickness of the synaptic cleft is big enough, then due to diffusion, the size of the activation zone of the postsynaptic membrane will grow to the size of the membrane. And our numerical calculations confirm this result.

\section{CONCLUSIONS}

The model proposed above describes the activation of the postsynaptic membrane. This includes different processes, starting from the mediator exocytosis into the synaptic cleft, then its diffusion, and, lastly, the interaction of the mediator with the receptors on the postsynaptic membrane. These processes are crucially important in spreading nerve impulses across the neuron systems. The received results allow us to understand the key features of the processes and to estimate their main characteristics. In particular, we have found that the size of the activation zone of the postsynaptic membrane is proportional to the size of the activation zone of the presynaptic membrane, and it is increases with increasing the thickness of the synaptic cleft.

Another important result is of a quantitative nature and is based on the possibility to calculate the number of activated receptors. Namely, using the model, we can calculate how the number of activated receptors changes with time, and how the activated receptors are distributed within the postsynaptic membrane. We hope that our methodology could be useful for handling possible physiological experiments. The general strategy for applying our results for experimental data could be based on the dimensional scaling of the parameters that are involved in the solution. The scaling parameters are to be found as a relation of measured experimental values to dimensionless parameters, calculated on the basis of the model. What is possible to state at the moment is that qualitatively our results are in agreement with experimental data (see, for example, [22]). To get more specific results, one has to adapt the model to the conditions of a particular experiment.
[1] Z. M. Bacq, Chemical Transmission of Nerve Impulses: A Historical Sketch (Pergamon, Oxford, 1975); https: //doi.org/10.1016/C2013-0-02752-1.

[2] H. W. Davenport, Physiologist, 34, 129 (1991).
[3] T. C. Südhof, R. C. Malenka, Neuron 60, 469 (2008); https://doi.org/10.1016/j.neuron.2008.10.011.

[4] M. R. Bennett, History of the Synapse (Harwood Academic Publishers, Amsterdam, 2001). 
[5] A. V. Chalyi, L. M. Chernenko, in Dynamical Phenomena at Interfaces, Surfaces and Membranes, edited by D. Beysens N. Boccara, G. Forgacs (Nova Science Publishers, New York, 1993), p. 457.

[6] A. V. Chalyi, E. V. Zaitseva, J. Phys. Stud. 11, 322 (2007).

[7] O. V. Chalyi, O. V. Zaitseva, Ukr. J. Phys. 54, 366 (2009).

[8] A. N. Vasilev, A. V. Chalyi, Ukr. J. Phys. 54, 1183 (2009).

[9] A. V. Chalyi, A. N. Vasilev, Phys. Alive 10, 32, (2000).

[10] A. N. Vasil'ev, A.V. Chalyi, Biophysics 55, 600 (2010); https://doi.org/10.1134/S0006350910040147.

[11] A. N. Vasilev, S. V. Kislyak, J. Phys. Stud. 14, 4801 (2010).

[12] S. I. Braichenko, A. N. Vasilev, J. Phys. Stud. 16, 4802 (2012) (in Ukrainian).

[13] A. N. Vasil'ev, A. V. Kulish, Biophysics 59, 304 (2014); https://doi.org/10.1134/S0006350914020262.

[14] A. V. Chalyi, A. N. Vasilev, E.V. Zaitseva, Condens. Matter Phys. 20 13804, (2017); https://doi.org/10. 5488/CMP. 20.13804.
[15] S. O. Rizzoli, W. J. Betz, Nature Rev. Neurosci. 6, 57 (2005); https://doi.org/10.1038/nrn1583.

[16] J. Trommershauser, R. Schneggenburger, A. Zippelius, E. Nehery, Biophys. J. 84, 1563 (2003); https://doi. org/10.1016/S0006-3495(03)74967-4.

[17] R. W. Holz, S. K. Fisher, in Basic Neurochemistry, edited by S. Brady, G. Siegel, R. W. Albers, D. Price (Elsevier, 2012), p. 235; https://doi.org/10.1016/ B978-0-12-374947-5.00012-2.

[18] J. Lichtenberger, P. Fromherz, Biophys. J. 92, 2266 (2007); https://doi.org/10.1529/biophysj. 106. 096446.

[19] S. E. Lauri et al., Neuron 50, 415 (2006); https://doi. org/10.1016/j.neuron.2006.03.020.

[20] R.G. Zhai, H.J. Bellen, Physiology 19, 262 (2004); https://doi.org/10.1152/physiol.00014.2004.

[21] M. Missler, T. C. Südhof, T. Biederer, Cold Spring Harb. Perspect. Biol. 4, a005694 (2012); https://doi .org/10. 1101/cshperspect.a005694.

[22] J. D. Clements, R. A. J. Lestert, G. Tong, C. E. Jahr, G. L. Westbrook, Science 258, 1498 (1992).

\title{
МОДЕЛЮВАННЯ ПЕРЕДАЧІ НЕРВОВОГО ІМПУЛЬСУ В СИНАПТИЧНІЙ ЩІЛИНІ
}

\author{
О. В. Куліш, О. М. Васильєв \\ Киїсъкий начіоналъний університет імені Тараса Шевченка, кафедра теоретичної фізики \\ вул. Володимирсъка, 64, Київ, 01601, Україна
}

\begin{abstract}
Запропоновано модель передачі нервового імпульсу через синаптичну щілину (хімічний синапс). Модель враховує дифузію медіатору в синаптичній щілині та його взаємодію з рецепторами на постсинаптичній мембрані. Розглянуто систему з двох рівнянь. Одне з них описує дифузію медіатору в синаптичній щілині, а інше - взаємодію медіатору з рецепторами на постсинаптичній мембрані. Цей процес ключовий у передачі нервового імпульсу, оскільки активація рецепторів приводить до генерування нового нервового імпульсу, який поширюється через контактний нейрон.

Знайдено аналітичний розв'язок для системи рівнянь і, базуючись на цьому розв'язку, розраховано деякі важливі характеристики, які визначають режим передачі нервового імпульсу. Зокрема встановлено, як кількість активованих рецепторів змінюється з часом і як ці активовані рецептори розподілені на постсинаптичній мембрані. Також обчислено розмір зони активації постсинаптичної мембрани й показано, що він пропорційний до розміру зони активації пресинаптичної мембрани. З'ясовано, як товщина синаптичної щілини впливає на активаційні характеристики синапсу. Показано, що зменшення товщини щілини зменшує розмір зони активації постсинаптичної мембрани
\end{abstract}

